http://ejournal.upi.edu/index.php/jaz - e-mail: jurnal.zonasi@gmail.com dan jurnal_zonasi@upi.edu doi.org/10.17509/jaz.v3i1.12400

\title{
KAMPUNG ISLAMI: PENGARUH PONDOK PESANTREN SURYALAYA DALAM PERKEMBANGAN PERMUKIMAN DI KAMPUNG GODEBAG
}

\author{
Article History: \\ First draft received: \\ 10 Agustus 2018 \\ Revised: \\ 11 September 2018 \\ Accepted: \\ 10 Februari 2019 \\ Final proof received: \\ Print: \\ 14 Juni 2019 \\ Online
}

17 Juni 2019

\author{
Shan Shan'; Marwoto ${ }^{2}$ \\ ${ }^{1}$ Program Studi S1 Arsitektur, Fakultas Teknik, Universitas Kebangsaan \\ ${ }^{2}$ Departemen Arsitektur, Fakultas Teknik, Universitas Kebangsaan, Indonesia \\ E-mail: sscharlynna@gmail.com, marwotopataruka@yahoo.com
}

Abstract: Kampung Godebag is a village located in Desa Tanjungkerta, Kecamatan Pagerageung, Kabupaten Tasikmalaya, West Java - Indonesia. Godebag village is famous for its nickname as Kampung Islami, all starting from the building of a mosque that is Nurul Anshar Mosque which is the forerunner to the establishment of Pondok Pesantren Suryalaya. With the establishment of Pondok Pesantren Suryalaya make the environment around the boardingers undergo many changes, in terms of infrastructure, livelihood, habits, social and cultural community. Godebag village becomes thick with Islamic nuances and improvements in the quality of education because of the many built education fasilites by the pesantren, the livelihood of many people who turned into entrepreneurship because of the many opportunities for entrepreneurship to meet the needs of the students at boarding schools and students from out of town. By conducting field surveys to related locations and additional data collection from the internet it can be seen what changes and developments are taking place in Kampung Godebag, the results of the research indicate that many people change their homes as entrepreneurs, especially those on the main access road Kompleks Pendidikan Pondok Pesantren Suryalaya.

Keyword: History, Settlement, Islamic Village.

\begin{abstract}
Abstrak: Kampung Godebag adalah sebuah kampung yang berada di Desa Tanjungkerta, Kecamatan Pagerageung, Kabupaten Tasikmalaya, Jawa Barat - Indonesia. Kampung Godebag terkenal dengan julukannya sebagai Kampung Islami, semua berawal dari di bangunnya sebuah masjid yaitu Masjid Nurul Anshar yang merupakan cikal bakal terbentuknya Pondok Pesantren Suryalaya. Dengan berdirinya Pondok Pesantren Suryalaya membuat lingkungan di sekitar pesantren mengalami banyak perubahan, dari segi infrastruktur, mata pencaharian, kebiasan, sosial dan budaya masyarakat. Kampung Godebag menjadi kental dengan nuansa islami dan peningkatan dalam kualitas pendidikan karena banyaknya dibangun fasilitas pendidikan oleh pihak pesantren, mata pencaharian masyarakat banyak yang berubah menjadi berwirausaha karena banyaknya peluang berwirausaha untuk memenuhi kebutuhan para santri di pesantren dan pelajar dari luar kota. Dengan melakukan survey lapangan ke lokasi terkait dan pengumpulan data tambahan dari internet dapat diketahui perubahan dan perkembangan apa saja yang terjadi di Kampung Godebag, hasil dari penelitian menyebutkan bahwa banyak dari masyarakat yang merubah rumah tingggal mereka sebagai tempat berwirausaha terutama yang berada di pinggir jalan utama menuju Kompleks Pendidikan Pondok Pesantren Suryalaya.

Kata Kunci: Sejarah , Permukiman, Kampung Islami.
\end{abstract}

\section{PENDAHULUAN}

\section{Latar Belakang}

Suryalaya adalah sebuah nama pondok pesantren yang terletak di Kabupaten Tasikmalaya, Jawa Barat. Pondok Pesantren Suryalaya dirintis oleh Syaikh Abdullah bin Nur Muhammad atau yang dikenal dengan panggilan Abah Sepuh sejak awal tahun 1905. Nama "Suryalaya" diambil dari istilah Sunda yaitu "Surya = Matahari" dan "Laya = Tempat Terbit". Jadi, Suryalaya secara harfiah mengandung arti "Tempat Matahari 
Terbit. Pesantren ini terkenal dengan "Inabah" sebuah program yang dikhususkan untuk mengobati para pecandu narkoba dengan metode dzikir.

Inabah adalah istilah yang berasal dari Bahasa Arab "anaba-yunibu" (mengembalikan), sehingga inabah berarti pengembalian atau pemulihan.

Metode ini mencakup :

- Mandi.

- Sholat.

- Talqin Dzikir

- Pembinaan

Disamping kegiatan-kegiatan tersebut, juga diberikan kegiatan tambahan berupa: Pelajaran baca AlQur'an, berdoa, tata cara ibadah, ceramah keagamaan dan olahraga. Setiap anak bina di evaluasi untuk mengetahui sejauh mana perkembangan kesehatan jasmani dan rohaninya. Evaluasi diberikan dalam bentuk wawancara atau penyuluhan oleh ustadz atau oleh para pembina inabah yang bersangkutan. Atas keberhasilan metode Inabah tersebut, KH.A Shohibulwafa Tajul Arifin mendapat penghargaan "Distinguished Service Awards" dari IFNGO on Drug Abuse, dan juga penghargaan dari Pemerintah Republik Indonesia atas jasajasanya di bidang rehabilitasi korban Narkotika dan Kenakalan remaja.

\section{Permasalahan dan Tujuan Penelitian}

Kampung Godebag yang terkenal dengan julukannya sebagai Kampung Islami memiliki latar belakang yang panjang dalam perkembangannya, untuk itu permasalahan yang akan dibahas dalam penelitian ini adalah Sejauhmana dan dalam hal apa saja perkembangan yang terjadi di Kampung Godebag hubungannya dengan adanya Pondok Pesantren Suryalaya ? Tujuan dari penelitian ini adalah untuk mengetahui perkembangan permukiman yang terjadi di Kampung Godebag.

\section{TINJUAN PUSTAKA}

\section{Definisi Permukiman}

Menurut Undang-Undang No 4 Tahun 1992 Pasal 3, Permukiman adalah bagian dari lingkungan hidup diluar kawasan lindung, baik yang berupa kawasan perkotaan maupun pedesaan yang berfungsi sebagai lingkungan tempat tinggal atau lingkungan hunian dan tempat kegiatan yang mendukung perikehidupan dan penghidupan. Satuan lingkungan permukiman adalah kawasan perumahan dalam berbagai bentuk dan ukuran dengan penataan tanah dan ruang, prasarana dan sarana lingkungan yang terstruktur (pasal 1 ayat 3). Pasal 4 Undang-Undang Nomor 4 Tahun 1992 menyebutkan bahwa penataan perumahan dan permukiman berlandaskan asas manfaat, adil dan merata, kebersamaan dan kekeluargaan, kepercayaan pada diri sendiri, keterjangkauan, dan kelestarian lingkungan hidup.

Undang-Undang No. 4 Tahun 1992 Tentang Perumahan dan Permukiman Pasal 4 menyebutkan bahwa penataan perumahan dan permukiman bertujuan untuk: 1 . Memenuhi kebutuhan rumah sebagai salah satu kebutuhan dasar manusia, dalam rangka peningkatan dan pemerataan kesejahteraan rakyat; 2. Mewujudkan perumahan dan permukiman yang layak dalam lingkungan yang sehat, aman, serasi, dan teratur; 3 . Memberi arah pada pertumbuhan wilayah dan persebaran penduduk yang rasional; 4. Menunjang pembangunan di bidang ekonomi, sosial , budaya, dan bidang-bidang lain. Pemenuhan kebutuhan permukiman diwujudkan melalui pembangunan kawasan permukiman skala besar yang terencana secara menyeluruh dan terpadu dengan pelaksanaan yang bertahap (Bab IV Pasal 18). Pembangunan kawasan permukiman tersebut ditujukan untuk menciptakan kawasan permukiman yang tersusun atas satuan-satuan lingkungan permukiman dan mengintegrasikan secara terpadu dan meningkatkan kualitas lingkungan perumahan yang telah ada di dalam atau di sekitarnya, yang dihubungkan oleh jaringan transportasi sesuai dengan kebutuhan dengan kawasan lain yang memberikan berbagai pelayanan dan kesempatan kerja. Pembangunan perumahan dan permukiman diselenggarakan berdasarkan rencana tata ruang wilayah perkotaan dan rencana tata ruang wilayah bukan perkotaan yang menyeluruh dan terpadu yang ditetapkan oleh pemerintah daerah dengan mepertimbangkan berbagai aspek yang terkait serta rencana, program, dan prioritas pembangunan perumahan dan permukiman.

\section{Permukiman Islami}

Permukiman yang proses terbentuknya berdasarkan ajaran agama Islam disebut dengan istilah Darussalam, yaitu pemukiman yang menimbulkan kesejahteraan dan keselamatan, hal ini disebabkan oleh 
rasa patuh masyarakat yang tinggal di permukiman tersebut dalam melaksanakan hukum-hukum Islam. Dar mempunyai arti rumah, perkampungan, wilayah, daerah, kawasan atau negara. Salam mempunyai arti keselamatan atau kesejahteraan. (Djarot, 1987).

\section{Awal Pembentukan Kampung Islami dengan Pembuatan Masjid Pondok Pesantren Suryalaya}

Kata masjid berasal dari bahasa Arab yaitu sajada-yasjudu yang artinya sujud. Dalam konteks yang lebih luas sujud merupakan sebuah ekspresi dari kepatuhan dan ketaatan seorang hamba kepada Tuhannya. Sujud adalah kemuncak kepatuhan dan penghinaan diri. (Serageldin, 1981). Perkataan masjid berulang sebanyak 28 kali dalam Al-Qur'an sebagaimana dalam QS Ar-Ra'd ayat 15 dan QS Al-Baqarah ayat 34.

\section{Karakter Ruang Terbuka}

Perencanaan permukiman Islam diutamakan pada penataan urban space untuk supra individual. Kelompok supra individual ini merupakan suatu bentuk kekeluargaan, keturunan dan persamaan fungsi (Lughod, 1987). Permukiman Islam bercirikan formalisme yang fleksibel dan arsitektur masyarakat muslim selalu memiliki hubungan yang erat dengan alam dan lingkungannya. Ruang-ruang muslim merupakan inti dari segala hubungan ekspresi yang koheren dari realitas sosio-kultural yang harmonis

(Serageldin, 1981).

Ruang-ruang muslim merupakan inti dari segala hubungan ekspresi yang koheren dari realitas sosiokultural yang harmonis (Serageldin, 1981).

\section{METODOLOGI PENELITIAN}

Metode yang digunakan adalah metode kualitatif (Creswell, 2008) yang bersifat deskriptif (Groat \& Wang, 2002), yaitu dengan mengkaji literatur yang berkaitan dengan Kampung Islami untuk diterapkan pada kasus. Fenomena - fenomena di dalam kasus tersebut dikaji dan dikaitkan dengan literatur mengenai Kampung Islami di Kampung Godebag.

\section{Metode Pengumpulan Data}

Metode pengumpulan data yang digunakan yaitu studi observasi pada kasus untuk melihat fenomena yang terjadi. Data primer yang digunakan merupakan data observasi-non-participant dan dokumentasi langsung ke lokasi. Sedangkan data sekunder diambil dari internet.

\section{HASIL PENELITIAN DAN PEMBAHASAN}

\section{Awal Mula dari Terbentuknya Kampung Islami di Kampung Godegag}

Menurut awal pembentukan kota, kota dengan perencanaan Islami diawali dengan pendirian masjid oleh Nabi Muhammad SAW pada pusat kota. Kemudian Nabi Muhammad SAW membagi-bagi lahan untuk khittahs (quarter), 'aataa (properties) dan dur (house) kepada muhajreen (kelompok immigrant pengikutnya), immigrant lainnya, suku asli tempat tersebut, 'an, ar (masyarakat asli pengikutnya), individu-individu yang lain. Proses ini dapat dilihat pada kota Medina. Pembagian wilayah seperti ini untuk memelihara kesatuan sosial dan hubungan antar suku. Untuk mengakomodasi interaksi dan hubungan sosial pada masyarakat, di dalam kota Islami terdapat fasilitas umum seperti pasar (market), square, area pendidikan dan pemerintahan. Dimana fasilitas umum ini barada di sekitar masjid (sebagai pusat penyebaran kota).

Sehingga dapat diperjelas pada gambar di bawah bahwa terdapat urutan dari masjid hingga rumah yang sifatnya berurutan dari publik-semi publik-semi privat-privat (Mortada, 2003). 

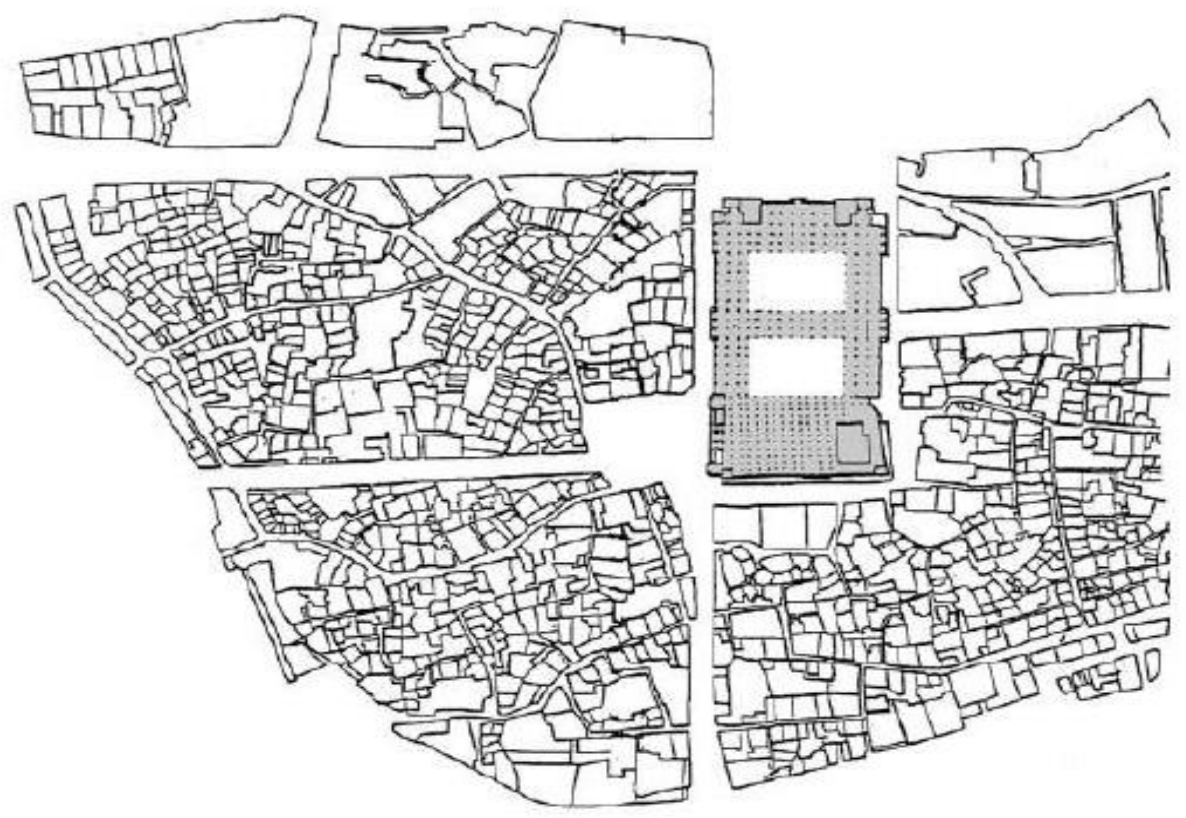

Gambar 1. Masjid yang dibangun oleh Nabi Muhammad SAW di Medina

Sumber : Hisham Mortada, 2003.

Masjid merupakan pusat penyebaran dari kota Islami, sehingga dapat dijelaskan pula bahwa merupakan pusat kegiatan dari masyarakat kota. Untuk itu, masjid dikelilingi dengan area komersial seperti suqs (pasar) kemudian citadel (pusat pemeritahan) serta area pendidikan (madrasah).
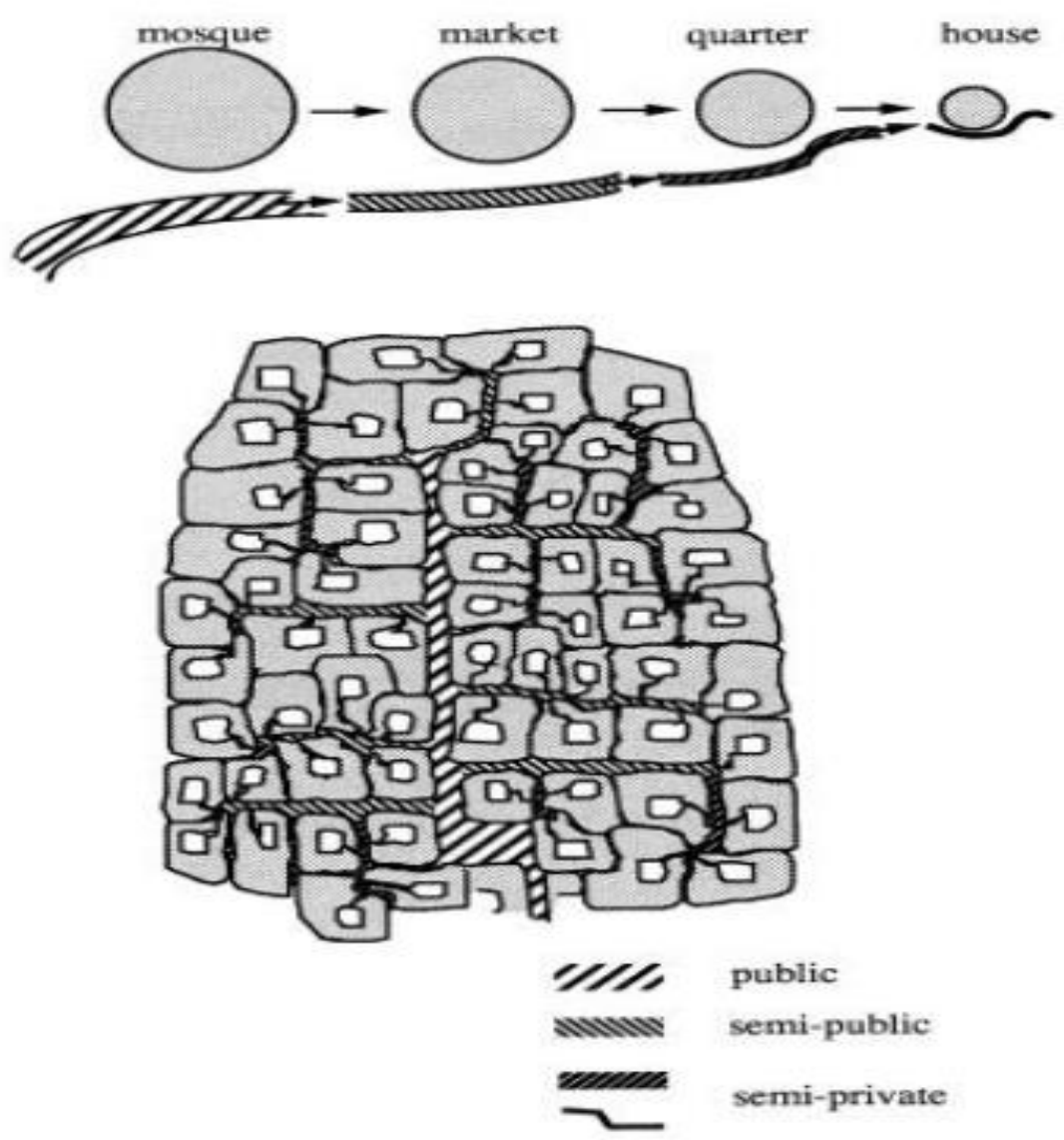

Gambar 2. Urutan masjid hingga rumah

Sumber : Hisham Mortada, 2003 


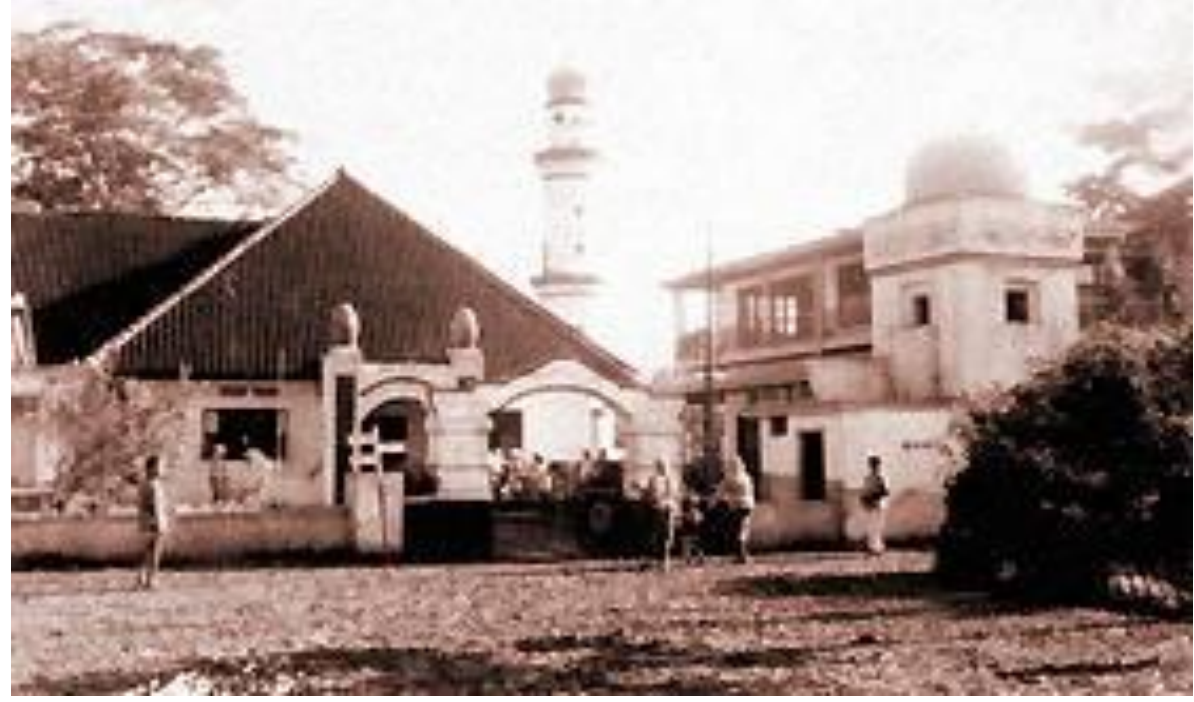

Gambar 3. Masjid Nurul Anshar tempo doeloe.

Sumber : google image

Kampung Islami di Kampung Godebag diawali dengan di bangunnya sebuah Masjid di Kampung Godebag yang merupakan cikal bakal dari Pondok Pesantren Suryalaya.

Masjid merupakan simbol dari suatu komunitas masyarakat yang mempercayai bahwa masjid sebagai faktor pemersatu kegiatan masyarakatnya dan berperan sebagai katalisator dalam pembangunan dan pengembangan masyarakatnya. Masjid juga merupakan tanda dari kehidupan religius dan menyatukan sifat dan kebersamaan umat muslim yang terwujud dalam keharmonisan kegiatan keagamaan, sosial, kemasyarakatan dan kehidupan budaya (Imammudin, 1985).

Begitupun di Kampung Godebag, selain menjadi tempat beribadah, Masjid menjadi sarana pemersatu kegiatan masyarakat disana, sebelum terbentuknya fasilitas-fasilitas yang lain banyak kegiatan yang di laksanakan di masjid seperti pertemuan antar masyarakat dalam bermusyawarah dan kegiatan belajar para santri Pondok Pesantren Suryalaya.

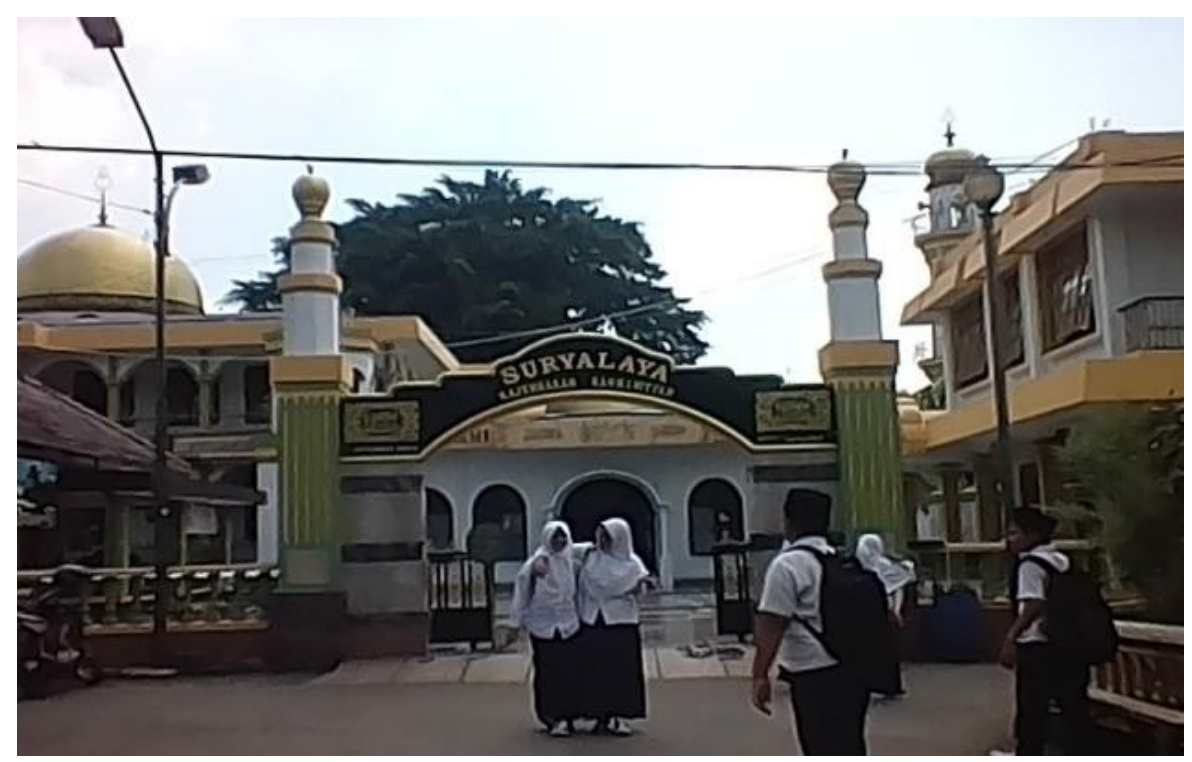

Gambar 4. Masjid dan Madrasah Pondok Pesantren Suryalaya

Sumber : Dokumentasi langsung penulis

Dalam perkembangannya, masjid merupakan tanda (sign) dan simbol (symbols), kepercayaan, ritual dan keagamaan yang diwujudkan dalam socioreligius dan institusi budaya yang terdapat dalam bentuk fisik dan orangorangnya (Oliver dan Paul dalam Imamudin, 1985). Komunitas masjid merupakan suatu produk yang dihasilkan dan membawa elemen-elemen tradisional dan modern. Arsitektur dapat menjelaskan konsepkonsep yang ada dan memiliki arti luas. Sehingga masjid juga dapat diartikan sebagai simbol kehidupan masyarakatnya yang diwujudkan dalam arsitektur sebagai ungkapan keagamaan (Imammudin, 1985). 


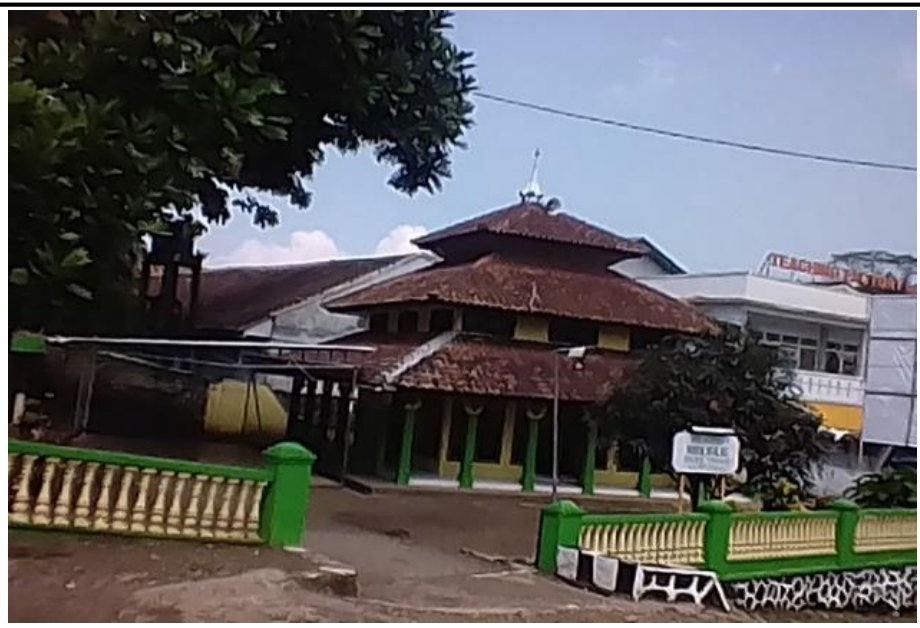

Gambar 5. Salah satu Masjid di Kampung Godebag

Sumber : Dokumentasi langsung penulis

Di Kampung Godebag terdapat banyak masjid, hal itu semakin mempertegas julukannya sebagai Kamping Islami.

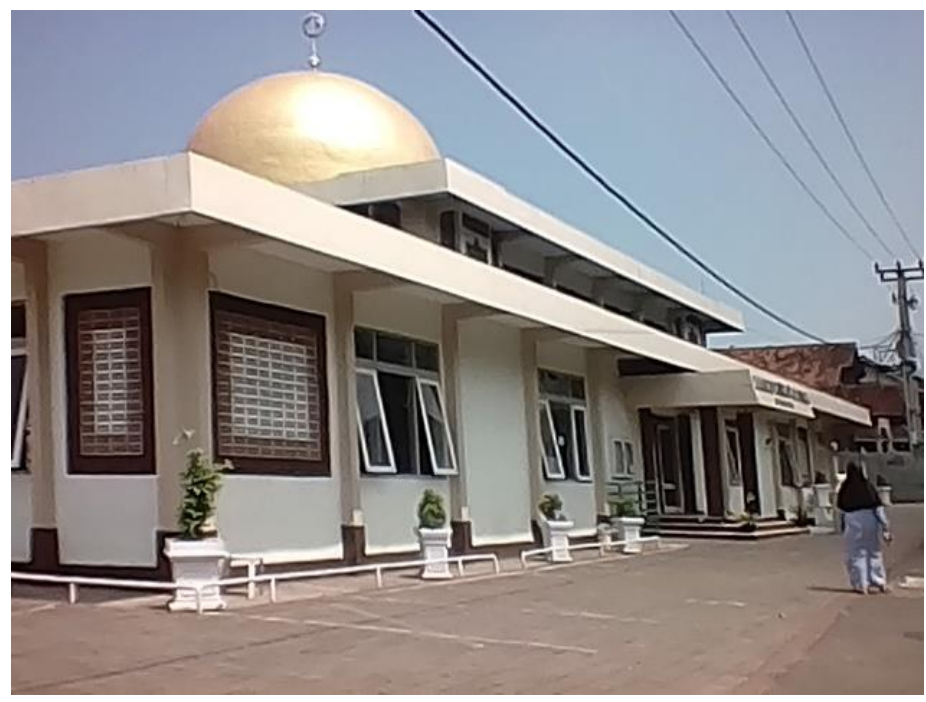

Gambar 6. Salah satu Masjid di Kampung Godebag

Sumber : Dokumentasi langsung penulis

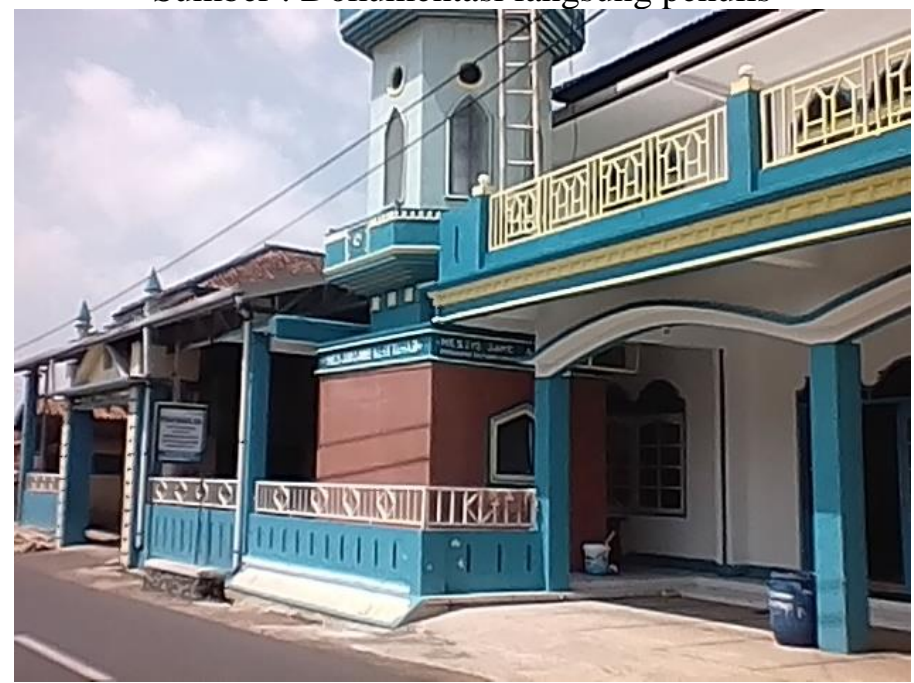

Gambar 7. Salah satu Masjid di Kampung Godebag

Sumber : Dokumentasi langsung penulis 


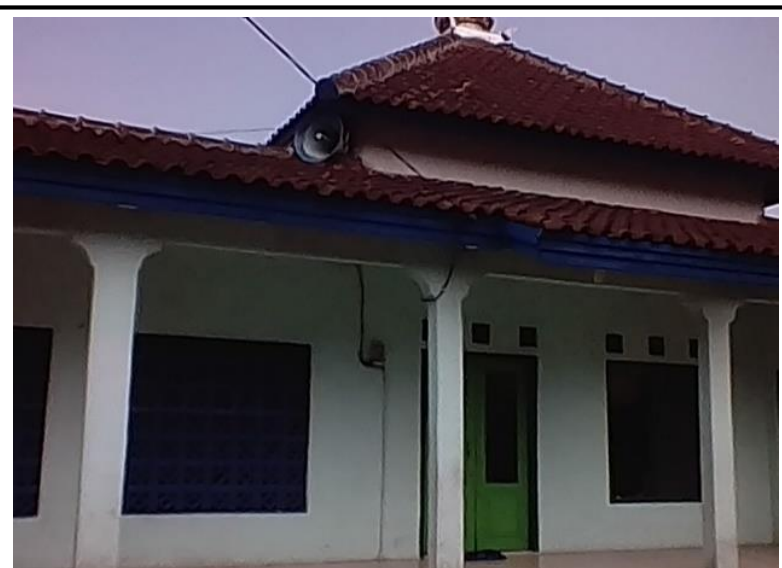

Gambar 8. Salah satu Masjid di Kampung Godebag

Sumber : Dokumentasi langsung penulis

Seiring perjalanan waktu, Pondok Pesantren Suryalaya semakin berkembang dan mendapat pengakuan serta simpati dari masyarakat, sarana pendidikan pun semakin bertambah, begitu pula jumlah pengikut/murid yang biasa disebut ikhwan. Dengan semakin banyak fasilitas pendidikan yang dibangun oleh Pondok Pesantren Suryalaya banyak masyarakat dari luar kota yang datang untuk menuntut ilmu atau sekedar berkonsultasi dengan pimpinan pondok pesantren dan membuatnya menjadi tujuan wisata religi.

Disana juga banyak dibangun pusat pendidikan formal dan non Formal yang dibangun oleh pihak pesantren.

\section{Pendidikan Formal Umum}

- Taman Kanak-kanak

- Sekolah Lanjutan Tingkat Pertama

- Sekolah Menengah Umum

- Sekolah Menengah Kejuruan

- Sekolah Tinggi Ilmu Ekonomi Latifah Mubarokiyah

- Madrasah Tsanawiyah

- Madrasah Aliyah

- Madrasah Aliyah Keagamaan

- Institut Agama Islam Latifah Mubarokiyah

Lembaga Pendidikan Non-Formal

- Pengajian Tradisional

Hal itu membuat daerah di sekitar Pondok Pesantren mengalami perubahan yang signifikan salah satunya adalah pengalih fungsian hunian di sekitar jalan utama menjadi tempat komersil, sehingga disana banyak warga yang berwirausaha berjualan macam-macam makanan dan pakaian juga barang-barang kerajinan

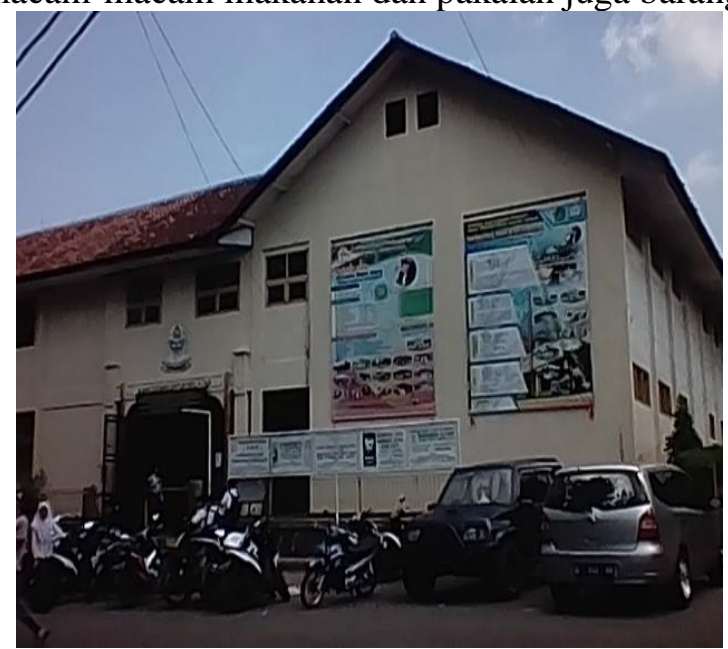

Gambar 9. Madrasah Tsanawiyah Suryalaya

Sumber : Dokumentasi langsung penulis 


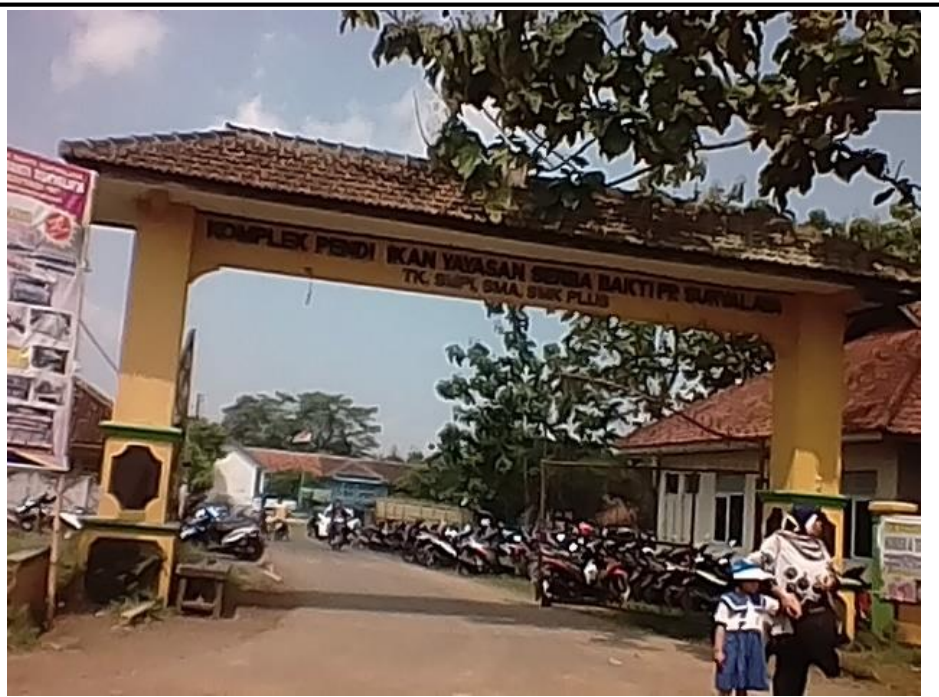

Gambar 10. Entrance Komplek Pendidikan Yayasan Serba Bakti Pondok Pesantren Suryalaya Sumber : Dokumentasi langsung penulis

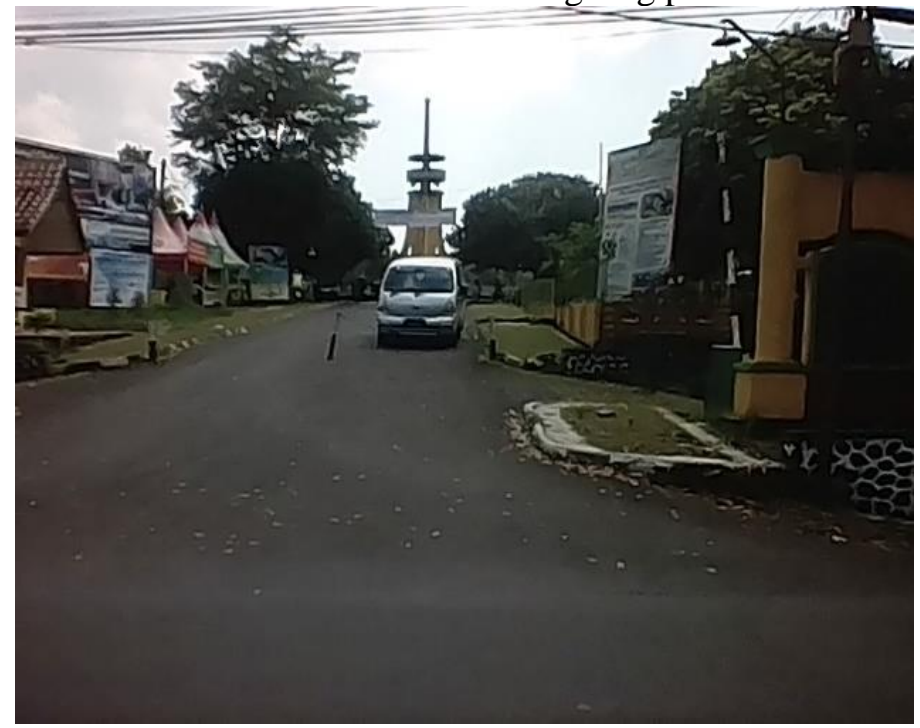

Gambar 11. STIE dan IAI Latifah Mubarokiyah

Sumber : Dokumentasi langsung penulis

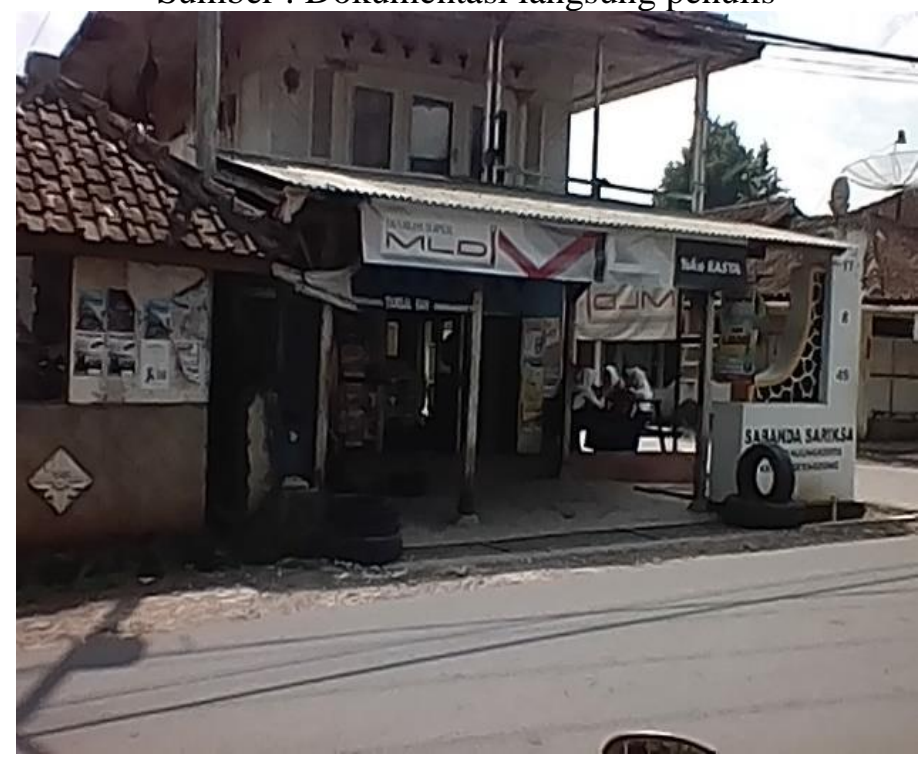

Gambar 12. Toko di depan Komplek Pendidikan Suryalaya Sumber : Dokumentasi langsung penulis 


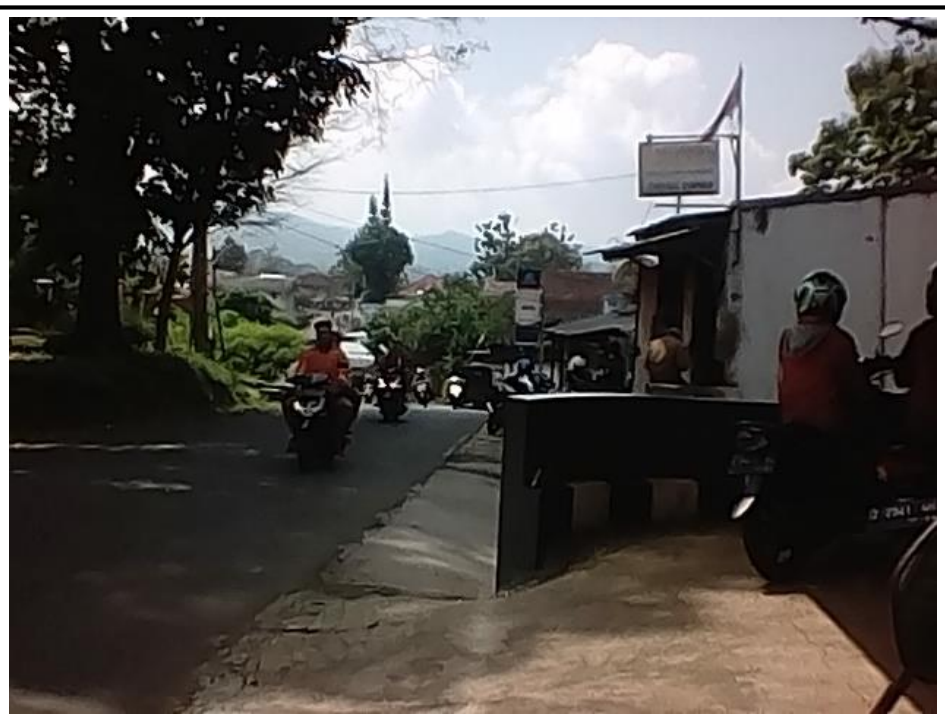

Gambar 13. Toko-toko di depan STIE dan IAI Latifah Mubarokiyah

Sumber : Dokumentasi langsung penulis

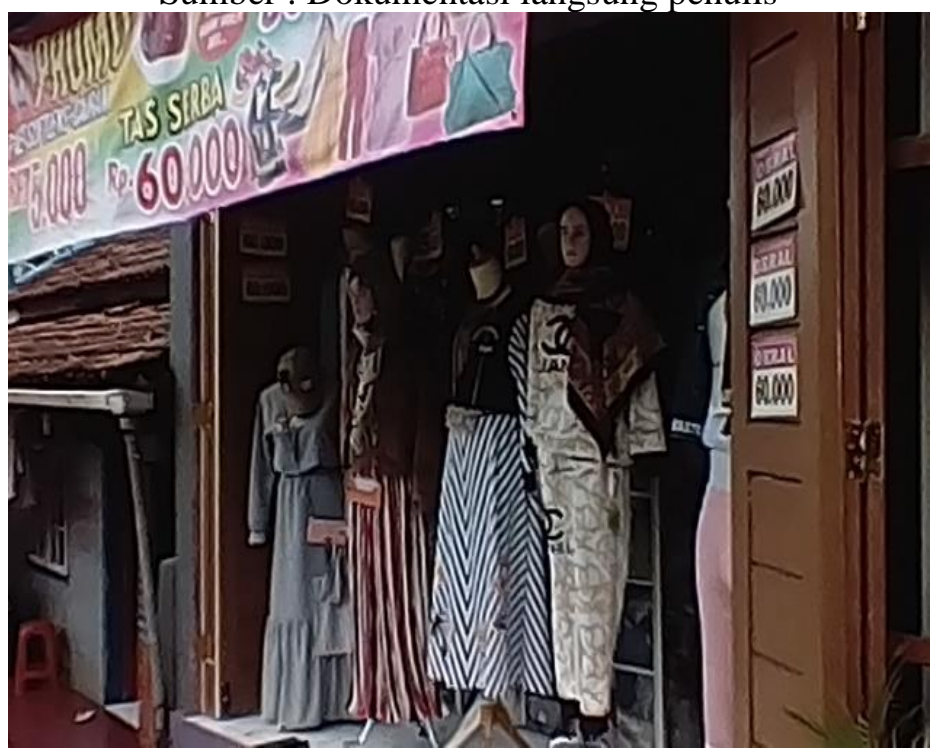

Gambar 14. Toko-toko di depan STIE dan IAI Latifah Mubarokiyah Sumber : Dokumentasi langsung penulis

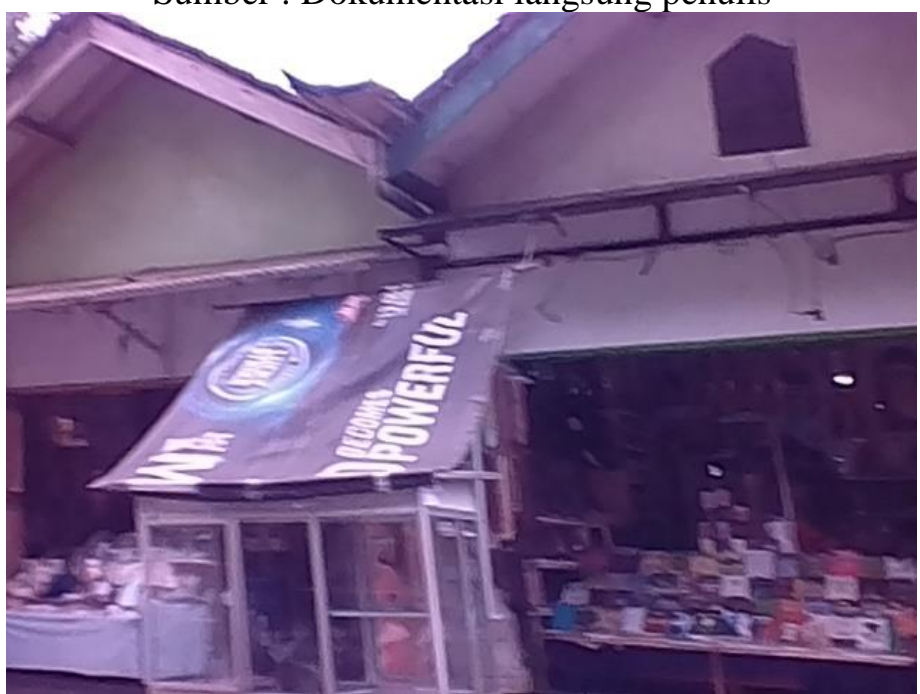

Gambar 15. Toko di depan Komplek Pendidikan Suryalaya Sumber : Dokumentasi langsung penulis 


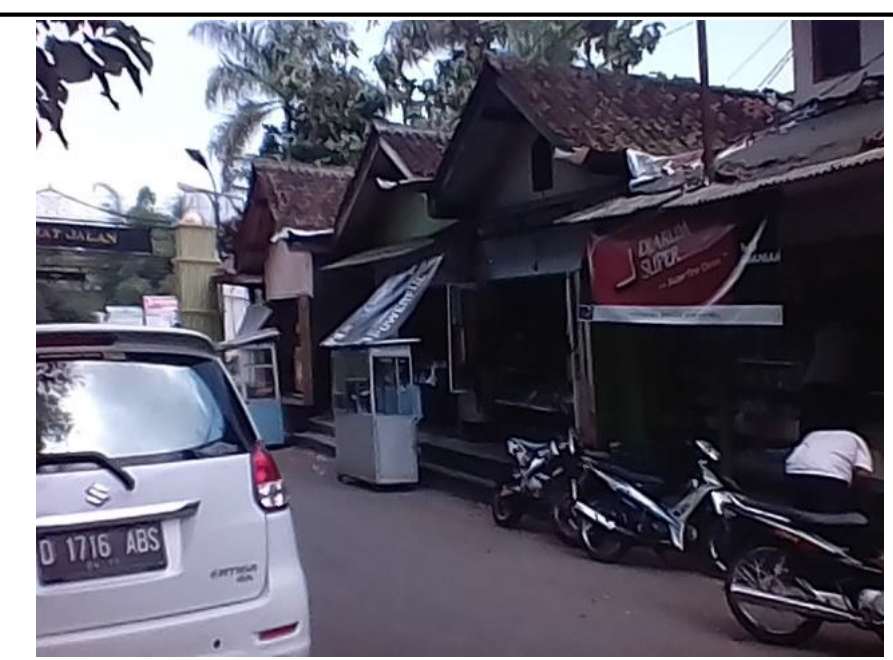

Gambar 16. Toko di depan Komplek Pendidikan Suryalaya

Sumber : Dokumentasi langsung penulis

Banyak warga yang membuka toko di depan rumahnya, mereka menjual macam-macam kebutuhan para santri yang belajar di sana, dimulai dari makanan, pakaian, alat tulis, dan lain-lain.

Daerah di sekitar Kampung Godebag berubah dengan cepat menjadi Pusat pendidikan Islam di Tasikmalaya dan daerah sekitar Pesantren Fasilitas pelengkap lainnya mulai dibangun dan membuat Kampung Godebag ramai dan maju dibanding kampung yang lainnya.

Pondok Pesantren Suryalaya juga terkenal dengan "Inabah" sebuah program yang dikhususkan untuk mengobati para pecandu narkoba dengan metode dzikir.

Inabah adalah istilah yang berasal dari Bahasa Arab "anaba-yunibu" (mengembalikan), sehingga inabah berarti pengembalian atau pemulihan. Maksudnya ialah proses kembalinya seseorang dari jalan yang menjauhi Allah ke jalan yang mendekat ke Allah. Istilah ini digunakan pula dalam Al-Qur'an yakni dalam Luqman surah ke31 ayat ke-15, Surat ke-42, Al-Syura ayat ke-10; dan pada surat yang lainnya. Abah Anom menggunakan nama inabah menjadi metode bagi program rehabilitasi pecandu narkotika, remaja-remaja nakal, dan orang-orang yang mengalami gangguan kejiwaan. Konsep perawatan korban penyalahgunaan obat serta kenakalan remaja adalah mengembalikan orang dari perilaku yang selalu menentang kehendak Allah atau maksiat, kepada perilaku yang sesuai dengan kehendak Allah atau taat. Metode ini mencakup :

- Mandi.

- Sholat.

- Talqin Dzikir

- Pembinaan

Disamping kegiatan-kegiatan tersebut, juga diberikan kegiatan tambahan berupa: Pelajaran baca Al-Qur'an, berdoa, tata cara ibadah, ceramah keagamaan dan olahraga. Setiap anak bina di evaluasi untuk mengetahui sejauhmana perkembangan kesehatan jasmani dan rohaninya. Evaluasi diberikan dalam bentuk wawancara atau penyuluhan oleh ustadz atau oleh para pembina inabah yang bersangkutan. Atas keberhasilan metode Inabah tersebut, KH.A Shohibulwafa Tajul Arifin mendapat penghargaan "Distinguished Service Awards" dari IFNGO on Drug Abuse, dan juga penghargaan dari Pemerintah Republik Indonesia atas jasa-jasanya di bidang rehabilitasi korban Narkotika dan Kenakalan remaja.

Inabah terletak di beberapa lokasi:

- Pondok Remaja Inabah I Malaysia : Kuala Nerang, Kedah, Malaysia

- Pondok Remaja Inabah VII : Kp. Rawa,Sukahening Rajapolah - Tasikmalaya

- Pondok Remaja Inabah XI : Kp. Ciseuti,Pagersari, Pagerageung - Tasikmalaya

- Pondok Remaja Inabah XIV : Pagerageung Kab. Tasikmalaya

- Pondok Remaja Inabah XVII Putri : Sukamulya, Cihaurbeuti Kab. Ciamis

- Pondok Remaja Inabah XVIII : Cijulang, Cihaurbeuti Kab. Ciamis

- Pondok Remaja Inabah XIX : Jl. Sidotopo Kidul No. 146-148 Surabaya

- Pondok Remaja Inabah XX : Desa Puteran, Kec. Pagerageung, Kab. Tasikmalaya

- Pondok Remaja Inabah XXIV : Sindangherang Kec. Panumbangan Kab. Ciamis 
- Pondok Remaja Inabah XXV : Banjarangsana, Kab. Ciamis

- Pondok Remaja Inabah XXVI : Desa Tanjungkerta, Kec. Pagerageung, Kab. Tasikmalaya

- Pondok Remaja Inabah XXVII : Pagerageung, Tasikmalaya

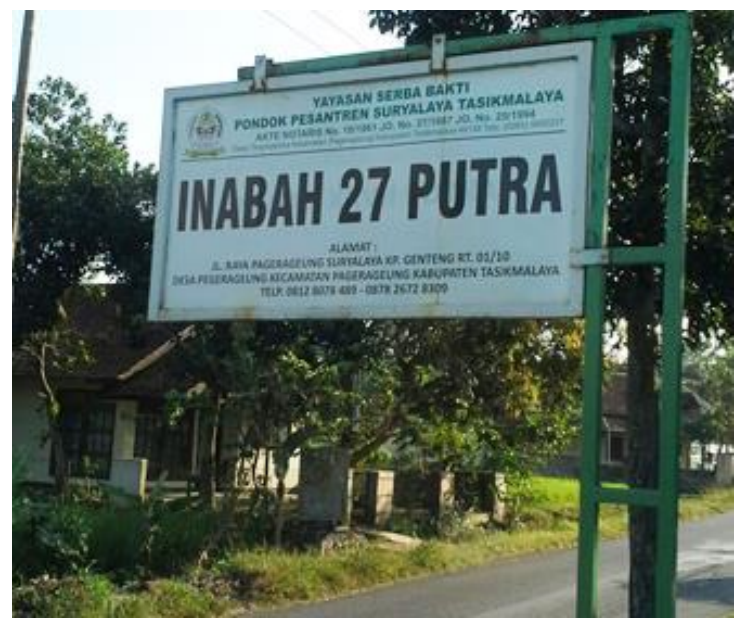

Gambar 17. Inabah 27 Putra

Sumber : Google Image

\section{Prinsip Habluminallah dan Habluminannas.}

Kampung Godebag memiliki konsep dari karakter Permukiman Islam yaitu Habluminallah dan Habluminannas (Permana, Susanti, dan Wijaya, 2018). Konsep ini dimaksudkan untuk menghadirkan sebuah permukiman yang seimbang dalam hubungan antara manusia dengan Tuhannya, manusia dengan manusia lainnya dan keselarasan manusia dengan alam sekitarnya. Dengan keseimbangan ini diharapkan dapat menjadikan manusia sebagai pengguna menjadi manusia (khalifah) yang tidak membuat kerusakan di muka bumi sebagai salah satu aspek ketaqwaan kepada Tuhannya.

Hal ini juga termuat dalam sebuah hadist yang diriwayatkan oleh Anas ra, Nabi Muhammad SAW bersabda : Allah SWT berfirman sebagai berikut :

"Terdapat 4 perkara, satu di antaranya menyangkut hubungan dengan Aku, satu menyangkut hubunganmu dengan hamba-hambaKu, satu untukmu dan satu untuk Aku. Adapun yang untuk Aku ialah bahwasanya engkau menyembah-Ku tidak menyekutukan sesuatu dengan Aku, sedang yang satu untuk engkau ialah bahwasanya apa yang telah engkau perbuat dari kebaikan Aku akan membalasmu. Adapun yang satu antara Aku dan engkau ialah bahwasanya engkau berdoa dan Aku menerima dan yang antaramu dan hambahambaKu ialah bahwasanya engkau merelakan bagi mereka apa yang engkau relakan bagi dirimu sendiri" (Riwayat Abu Nu'aim).

Dalam hadist tersebut diterangkan bahwa terdapat beberapa perkara penting, salah satunya keharusan untuk selalu mengedepankan hubungan manusia dengan Allah (habluminallah) tanpa melupakan hubungan dengan sesama manusia (habluminannas).

\section{Prinsip Habluminallah}

Prinsip habluminallah ini pada dasarnya menaungi habluminannas. Adapun nilai-nilai yang terkandung dalam konsep habluminallah adalah sebagai berikut (Tajuddin, 2003) :

\section{Nilai pengingat akan Keesaan dan Keagungan Allah SWT}

Nilai ini bertujuan meletakkan fokus manusia sebagai khalifah, dipertanggungjawabkan sebagai pemimpin di bumi dengan nilai-nilai yang baik. Manusia mudah menerima dan menyampaikan pesan melalui komunikasi visual. Hal ini merupakan suatu pendekatan terbaik, membawa kepada sesuatu pesan kolektif, terutama dalam proses menyampaikan peringatan manusia untuk meng-Esakan Tuhannya seperti mana dituntut oleh Islam. 
Terdapat berbagai pendekatan baik secara fisik, aktivitas manusia dan juga elemen simbolik yang dapat membantu masyarakat memikirkan dan mengulangi kajian akan pesan ke-Esaan Allah SWT. Elemen-elemen yang melingkupi kehidupan beragama dan juga obyek alam ciptaan Allah dipercaya dapat membawa sedikit banyak peringatan masyarakat kepada penciptanya.

Dengan di bangunnya banyak masjid dan pusat kegiatan dakwah di Kampung Godebag hal itu bertujuan agar masyarakat selalu ingat kepada Alloh S.W.T.

\section{Nilai pengingat akan ibadah ritual}

Dalam Islam, konsep ibadah mencakup skup yang begitu luas dan merangkumi segenap aspek kehidupan. Untuk bangunan masjid, mushalla atau sesuatu ruang untuk memudahkan manusia beribadah perlu dibina di tempat-tempat strategis dan orientasi yang mudah untuk dicapai dan dilihat.

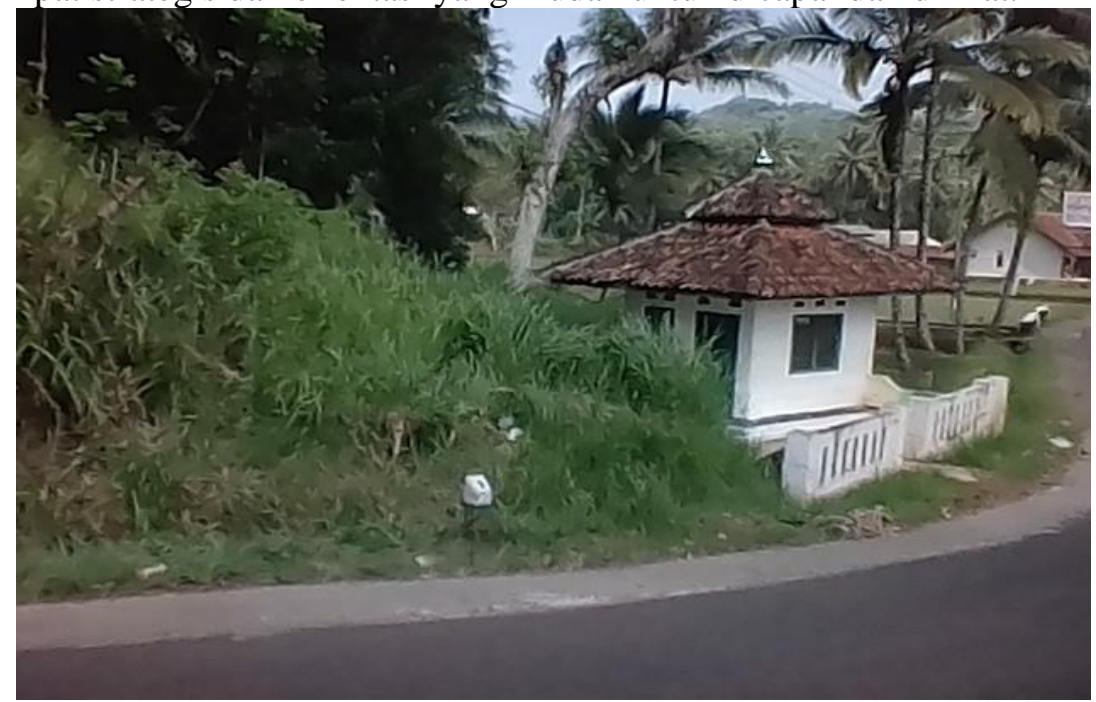

Gambar 18. Mushalla di Kampung Godebag.

Sumber : Dokumentasi langsung Penulis.

Begitupun di Kampung Godebag, untuk memudahkan masyarakat untuk melakukan ibadah di bangunlah Mushalla dan tempat bersih-bersih di sekitar area pesawahan, hal itu bertujuan agar ketika datang waktu shalat orang-orang yg sedang bekerja dapat melaksanakan shalat terlebih dahulu.

\section{Nilai pengingat atas kejadian alam ciptaan Allah SWT}

Peringatan kepada kejadian alam ciptaan Allah SWT dapat dilakukan dengan penggunaan bahan, orientasi bangunan dan metodologi perancangan suatu permukiman atau bangunan. Penggunaan bahan-bahan dari yang berasal dari alam seperti batu dan kayu akan menciptakan suatu image arsitektur tersendiri yang dekat alam.

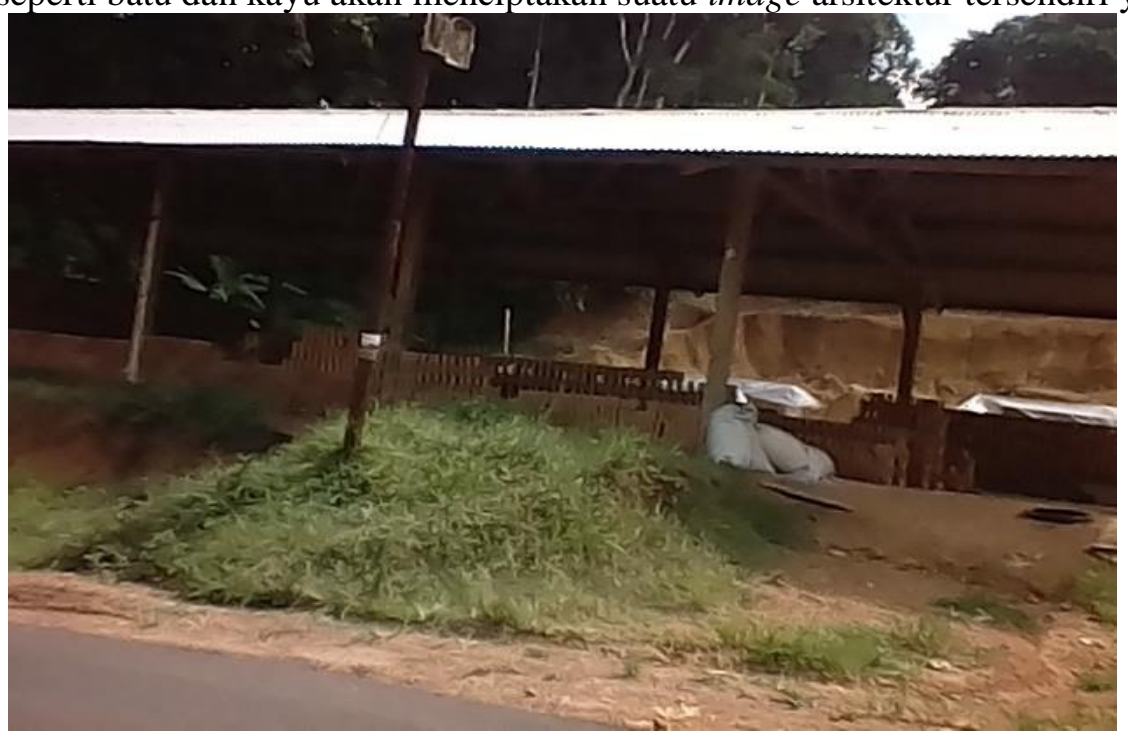

Gambar 19. Tempat pembuatan batako dan pemotongan kayu di Kampung Godebag.

Sumber : Dokumentasi langsung Penulis. 
Masyarakat di Kampung Godebag juga memanfaatkan hasil alam untuk dipergunakan dalam pembangunan rumah-rumah disana dan untuk di jual ke tempat lain.

\section{Nilai pengingat kepada kematian}

Selanjutnya, elemen ketiga yang membawa kepada peringatan adalah pesan kehidupan di dunia yang hanya bersifat sementara dan unsur kematian sebagai pemutus alam di dunia. Dalam perencanaan suatu permukiman, elemen yang paling jelas untuk dapat menyampaikan pesan ini adalah keberadaan makam.

Keberadaan makam atau TPU di Kampung Godebag juga terawat dan berada di samping area pesawahan. Hal itu bertujuan agar orang-orang selalu ingat dengan kematian walau saat sedang bekerja.

\section{Prinsip Habluminannas}

Nilai-nilai yang terkandung dalam konsep habluminannas (Tajuddin, 2003) adalah sebagai berikut :

\section{Ukhuwah dan integrasi sosial}

Ukhuwah adalah hubungan persaudaraan dengan seluruh masyarakat. Menjalin ukhuwah merupakan hal penting untuk membina hubungan antar masyarakat dan mengurangi kesenjangan sosial. Ukhuwah dapat mengikis perasaan individualis yang ada pada diri masyarakat. Islam meletakkan pembangunan sosial sebagai salah satu perkara utama setelah tanggung jawab diri. Kedua pembangunan ini perlu berjalan searah dan seimbang.

\section{Pembangunan ruang terbuka}

Pembangunan ruang terbuka merupakan salah satu hal yang penting. Karena di sinilah hubungan ukhuwah akan berlangsung dan terjalin. Di dalam Islam, setiap individu bertanggung jawab kepada kebajikan masyarakat, sehingga informasi dari masyarakat perlu difasilitasi seluas-luasnya.

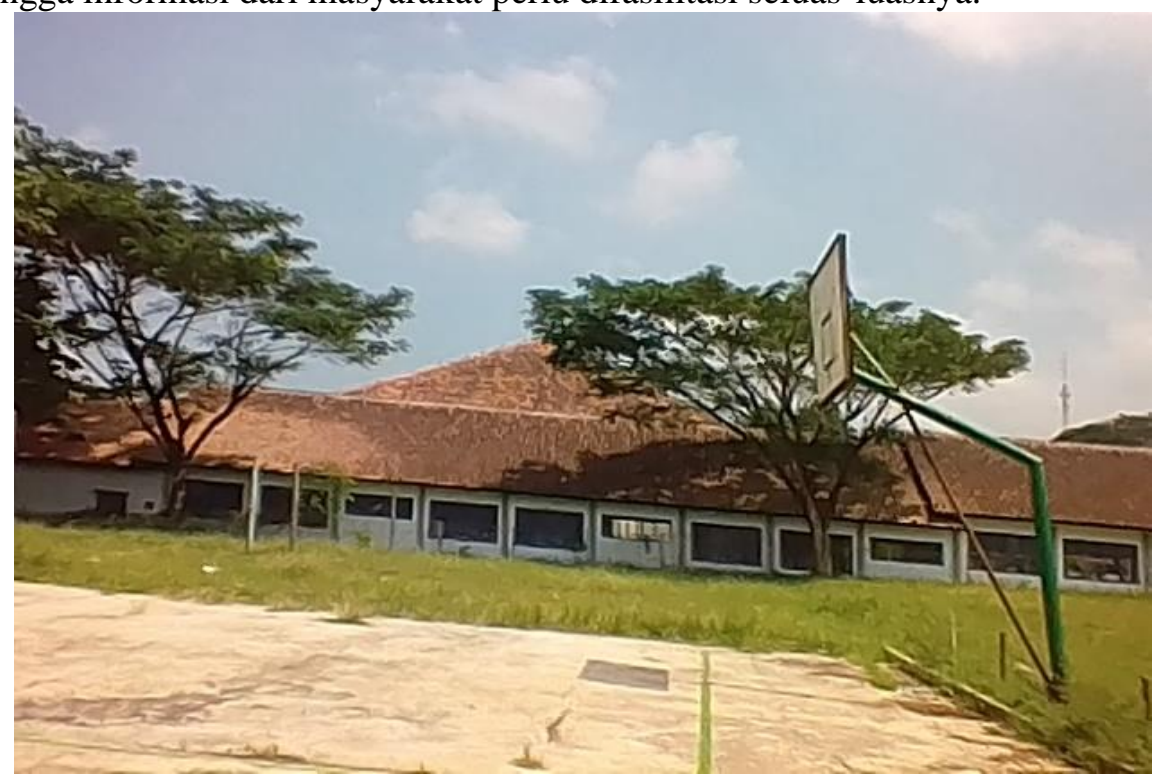

Gambar 20. Lapangan basket dan Lapangan Bola di Kampung Godebag.

Sumber : Dokumentasi langsung Penulis.

Di kampung Godebag juga tersedia fasilitas olahraga untuk pelajar dan masyarakat sekitar sebgai ruang terbuka, disinilah tercipta hubungan antara manusia satu dan lainnya.

\section{Pendidikan masyarakat}

Salah satu faktor yang sama pentingnya dengan pembangunan fisik ruang adalah faktor pendidikan masyarakat. Masyarakat perlu mendapatkan pendidikan serta arahan yang dapat memberikan kesadaran kepada mereka akan pentingnya hubungan ukhuwah dan pembangunan sosial. Di dalam permukiman Islam, pendidikan masyarakat ini diimplementasikan dengan adanya fasilitas-fasilitas pendidikan seperti sekolah atau madrasah, perpustakaan atau ruang-ruang yang dirasakan perlu untuk dijadikan sebagai pusat aktifitas berkumpulnya masyarakat untuk mendapatkan sebuah pendidikan. 


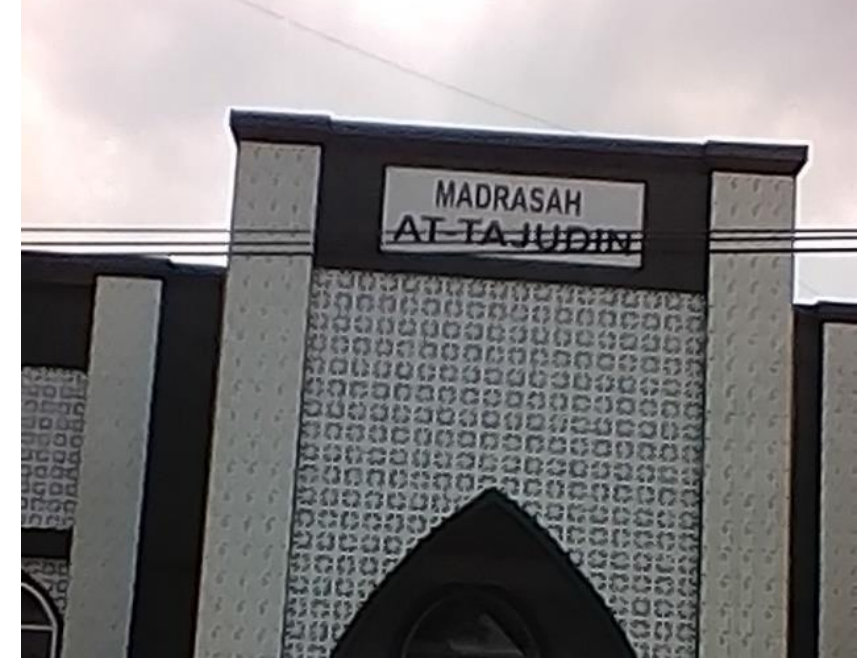

Gambar 21. Salah satu Madrasah di Kampung Godebag.

Sumber : Dokumentasi langsung Penulis.

Di Kampung Godebag memang lekat dengan pendidikan islami dari mulai Paud sampai Universitas hampir semuanya bernuansa islami.

\section{Nilai pengingatan terhadap toleransi kultural}

Allah SWT menciptakan manusia terdiri dari berbagai bangsa dan ras, namun hal ini tidak menjadi sumber perpecahan, karena dalam Islam ukuran derajat seseorang di mata Allah SWT terletak pada ketaqwaan dan keimanannya. Hal ini menegaskan bahwa adalah suatu kewajiban untuk menghormati budaya dan kehidupan sosial masyarakat. Selama tidak bertentangan dengan ajaran Islam, kita diperbolehkan menggunakan bahasa arsitektur masyarakat setempat dengan memanfaatkan potensi dan material yang ada pada permukiman tersebut. Hal ini menjadi prinsip yang juga menjadi karakter dari permukiman Islam.

\section{KESIMPULAN}

Dengan di bangunnya Pondok Pesntren Suryalaya membuat Kampung Godebag menjadi sebuah kampung yang bernuansa islami dan lebih maju dalam hal ekonomi dan pendidikan dibandingkan dengan kampung-kampung lain di sekitarnya. Konsep Permukiman Islam yaitu Habluminallah dan Habluminannas tercipta sangat baik disana. Keberadaan Masjid yang dibuat hampir setiap 200 meter di pinggir jalan utama menjadi ciri khas dan menguatkan julukannya sebagai Kampung Islami.Perkembangan yang terjadi tidak luput dari bertambahnya pembangunan fasilitas-failitas pendidikan oleh Pondok Pesantren suryalaya di sekitar Permukiman masyarakat.

\section{SARAN}

Penulis berharap untuk ke depannya Kampung Islami di Kota dan Kabupaten Tasikmalaya bukan hanya ada di kampung godebag sehingga dapat semakin terlihat dan menguatkan julukan Kota dan Kabupaten Tasikmalaya sebagai Kota Santri.

\section{UCAPAN TERIMA KASIH}

Terimaksih Penulis ucapkan kepada Alloh S.W.T atas limpahan rahmat dan karuniaNya sehingga Penulis dapat melaksanakan dan menyelesaikan penelitian ini, kepada Bapak Karto Wijaya, ST. , MT. atas bimbingan dan sarannya dan kepada pihak-pihak yang telah membantu yang tidak dapat Penulis sebutkan satu persatu.

\section{DAFTAR PUSTAKA}

Al-Qur'an dan Terjemahannya. 2014. Jakarta: Departemen Agama RI.

Creswell, John W. (2008). Research Design, Pendekatan Kualitatif, Kuantitatif, dan Mixed, Edisi Ketiga. Pustaka Pelajar, Bandung.

Fu'ad Abdul Baqi, Muhammad. 2017. Buku Kumpulan Hadits Shahih Bukhari Muslim. Insan Kamil.

Groat, Linda N., Wang, David. 2002. Architectural Research Methods. 
Imamuddin, Abu H, 1985, Exploring Architecture Islamic Cultures 2, Regionalism In Architecture : Proceeding of the Regional Seminar in the series Exploring Architecture in Islamic Institute of Architects Bangladesh, Held in Dhaka, Bangladesh, Concept Media Ptc.Ltd, Singapore.

Lughod, Janet L. Abu, 1987, The Islamic City-Historic Myth, Islamic Essence and Contemporary Relevance, International Journal of Middle East Studies, Cambridge University Press.

Maharani Ratna, Aditha 2013. Karakter Permukiman Islam Pada Kampung Arab Al Munawar Di Palembang. Masters Thesis, Undip.

Mortada, Hisham, 2003, Traditional Islamic Principles of Built Environment, Taylor \& Francis e-library, New York.

Permana, A. Y., Susanti, I., dan Wijaya, K. (2018). The Transformation of Gegerkalong Girang Area, Bandung City: amid Educative and Religious Areas. IOP Conference Series: Earth and Environmental Science, 213(1), 012022. https://doi.org/10.1088/1755-1315/213/1/012022

Sensa S, Djarot, S. Muhammad,. 1987. Sebuah Pemikiran Tentang Permukiman Islami. Bandung: Penerbit Mizan.

Serageldin, Ismail, 1981, The Arab City, Its Character and Islamic Cultural Heritage : Proceedings of a symposium held in Medina, Kingdom of Saudi Arabia, Arlington, USA.

Tajuddin, Mohammad, 1999, Konsep Perbandaran Islam, Fakulti Bina Alam UTM, Malaysia.

Undang-undang Republik Indonesia Nomor 4 tentang Permukiman. (1992). Surabaya: Usaha Nasional.

Wikipedia bahasa indonesia. Pondok Pesantren Suryalaya. 